\title{
質量スペクトルの簡単なディジタル記録方法
}

\section{A Simple Method for Digital Recording of Mass Spectra}

\author{
竹下 功* \\ ISAO TAKESHITA
}

(1972年11月16日受理)

\begin{abstract}
A simple method has been developed for digital measurement and recording of mass spectra. The system consists of a peak memory, a maximum detector, a measure command generator, an automatic reset signal generator and a conventional autorange digital voltmeter.

It can measure the peak height of mass spectra from $3 \mathrm{mV}$ to $10 \mathrm{~V}$. The precision is within $\pm 0.5 \%$ for the input signal higher than $30 \mathrm{mV}$.
\end{abstract}

\section{1. 緒言}

質量スペクトルの記録は従来ペンレコーダーあるい は電磁オッシログラフを用いて記録紙上にアナログ記 録を行ない, 後でベースラインからピークトップまで の高さをスケールで読み取り数值化することが行なわ れてきた。この方法は実際にはかなり手数な作業であ つた。

また，質量スペクトルは強度の変化が大きいため記 録計で記録する場合ひんぱんに感度の切換えを行なわ ねばならないが，次々に現われるピークの高さを予測 できない場合には完全な記録をすることはしばしば困 難であり，測定者の大きな負担となっていた。このた め, 記録計の自動レンジ化や感度の異なる複数の記録 計を用いる方法がとられている。

近年ディジタル電圧計が普及してきたが，精度が高 くまた多くのものは自動可変レンジの機能を持ってい るので，これを質量スペクトルの測定に用いることが できれば非常に便利であり，ディジタルプリンターを 並用して質量スペクトルのディジタル記録が可能とな る。

もとより質量スペクトルのディジタル記録は電子計 算機を用いる方法がむしろ本筋であるかも知れないが,
現状では何処でも使えるというわけにはいかない。こ のような観点から，イオン電流測定用のエレクトロメ ーターの出力をディジタルボルトメーターで測定, 記 録するための方法を検討した。

\section{2. 基本的な構成}

質量スペクトルは時間的な増減のはげしい線状のス ペクトルであるから，その極大值を正確に測定するた めには，ディジタルボルトメーター（以下 D. V. M. と書く)が測定を終えるまでの時間,極大值を保持して おく必要がある。測定時間は機種によるが 大体 200 $\mathrm{msec}$ 程度が必要である。ステップ応答時間はこれよ り長く，ここで使用した D. V. M.**では 3 秒以上必要 となっているが，通常の掃引速度ならばピークの立上 り時間を含めてほぼ追従できると考えられる。

以上のことから質量スペクトルを D. V. M. で測定 するには, 入力信号の極大值を保持する記憶回路と, 極大值に達したことを判断して測定指令を出す回路と， 計測が終了すれば次のスペクトルピークの到来に備え て先に保持した值を消去する回路すなわちリセット回 路が必要である。Fig. 1 はこの基本動作を示すブロッ ク困である。

* 松下電器産業株式会社無線研究所 (大阪府門真市門真 1006)

Wireless Research Lab., Matsushita Elec. Ind. Co., Ltd. (Kadoma, Osaka, Japan).

** 松下通信工業製 VP-261 A 


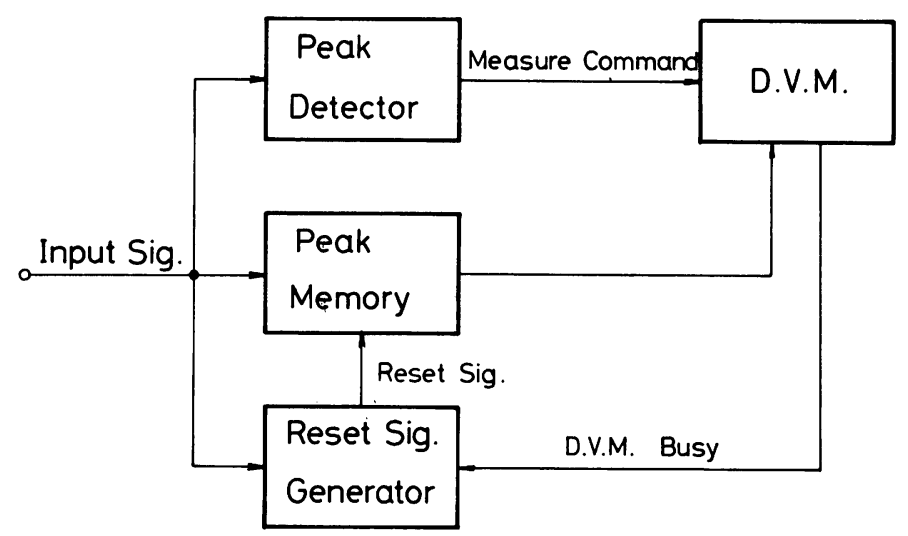

Fig. 1. Block diagram of the digital measurement system.

\section{3. 極大值保持回路}

質量スペクトルを記録するためにピーク值を一時保 持して測定しようという考え方は, 古くから門田 ${ }^{1)}$, 鈎 ${ }^{2)} と ゙ に よ り$ 発表されている。Fig. 2 に例示したよ うに,これらの方法は比較的簡単な二極管とコンデン サーを用いたもので，消去はスイッチを手動すること により行なっている。このような単純な回路では, 特 に入力信号が小さい時に二極管の順方向抵抗が無視で きなくなり, 入力信号とコンデンサーの両端の電圧に かなりの差が出てくる。

精密な極大値保持回路の回路例はオペレーショナル アンプのハンドブック ${ }^{3)}$ などにいろいろ出ているが, ここではFig. 3 に示す回路を使用した。これは負の入

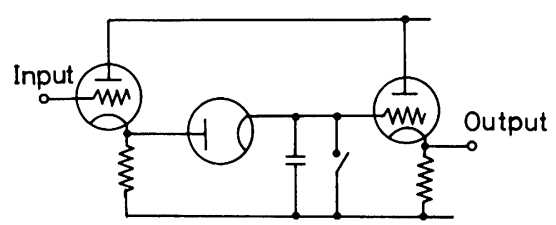

Fig. 2. Principle of a peak memory circuit used in the past.

力信号の極大值を保持する回路で, 全体として利得 1 の負帰還増幅器を構成しているから, 出力の絶対值が 入力のそれより低い間は $\mathrm{C}_{1}$ は充電され続ける。

ここで用いる增幅器 $\left(\mathrm{A}_{1}\right)$ の入力バイアス電流は十 分に小さいものでなければならない。通常のオペレー ショナルアンプでは $10 \mathrm{nA}$ 位あるから, もし $\mathrm{C}_{1}$ が

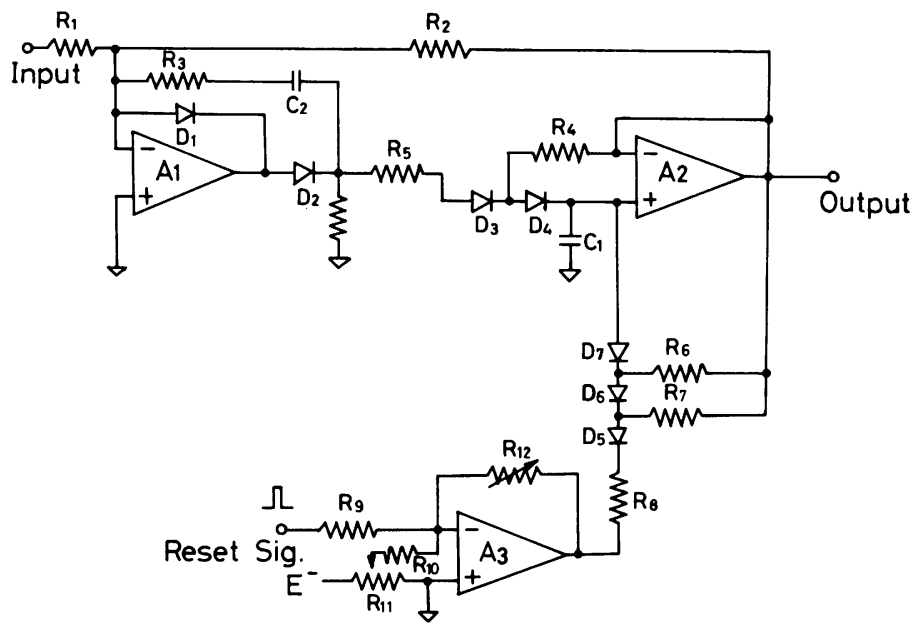

Fig. 3. Peak memory circuit and the reset circuit. 
$10 \mu \mathrm{F}$ 程度なら $10 \mathrm{mV}$ に充電された場合は 1 秒でそ の電荷は消費されてしまう。したがって，入力段に F E T を用いたオペレーショナルアンプが必要である。 この場合, 入力バイアス電流は 10 100 pA であるか ら上記の場合 $10^{2} \sim 10^{3}$ 秒である。この值でもなお不十 分なように思えるが, 実際に保持する必要な時間は 1 秒 以下であるから誤差は十分に小さいといえる。なお，ダ イオード $\mathrm{D}_{4}$ は洩れ電流を少なくするためにその両端の 電位差が零になるよう負帰還がかけられている。

消去信号は, 後で述べるが, 負のパルスを増幅器 $\mathrm{A}_{3}$ の出力に生ぜしめ $\mathrm{D}_{5}, \mathrm{D}_{6}, \mathrm{D}_{7}$ を通して $\mathrm{C}_{1}$ に蓄えら れた電荷を放電せしめるようにしてある。これは, $\mathrm{C}_{1}$ に高い正の電圧を保持せしめうるようにするためには保 持動作中 $\mathrm{A}_{3}$ の出力は同様に高い正の電圧に保たれな ければならないが，その結果小さい信号を保持してい る時にはダイオード $\mathrm{D}_{5}, \mathrm{D}_{6}, \mathrm{D}_{7}$ には高い逆電圧がか かり洩れ電流の影響が大きな誤差となるため, 特に洩 れ電流が少なくなるよう 3 段としたものである。

\section{4. 測定指令発生回路}

通常 D. V. M. を外部制御で使う場合は $10 \mathrm{msec}$ 位 のパルスが必要であるが, 問題はこの制御パルスを出 すタイミングをどのようにして知るかということであ る。すなわち, 入力信号が $1 つ の$ 極大値に達した時点 ないしはその時点よりある時間遅らせてこのパルスを 出せばよいが, 入力が極大值に達したことを確実に知 る方法をどのようにするかが問題である。

まず入力信号を微分してその微分信号の符号が変わ る時点を何等かの方法で知り，これを極大值に達した 時点と考える方法がある。

もう $1 つ の$ 方法は, 入力信号と極大值保持回路の出 力信号の絶対値を常に比較し, 差が生じた場合に極值 に達したと考える方法である。われわれは前者がパル ス的な雑音に幾分弱く誤動作の危険が多いという点で 後者の方法を採用した。Fig. 4 はこの回路の構成を示 すブロック図であり，同図右側に各部分の信号波形を 模式的に示した。Fig. 4 の単安定マルチバイブレーター は D. V. M.のステップ応答時間を考虑して極大值通過 後一定時間後に測定指令が出るように時定数を選んだ。

\section{5. 消去信号発生回路}

次々に到来する質量スペクトルを自動的にディジ夕 ル測定をしてゆくためには，入力信号を保持回路に保

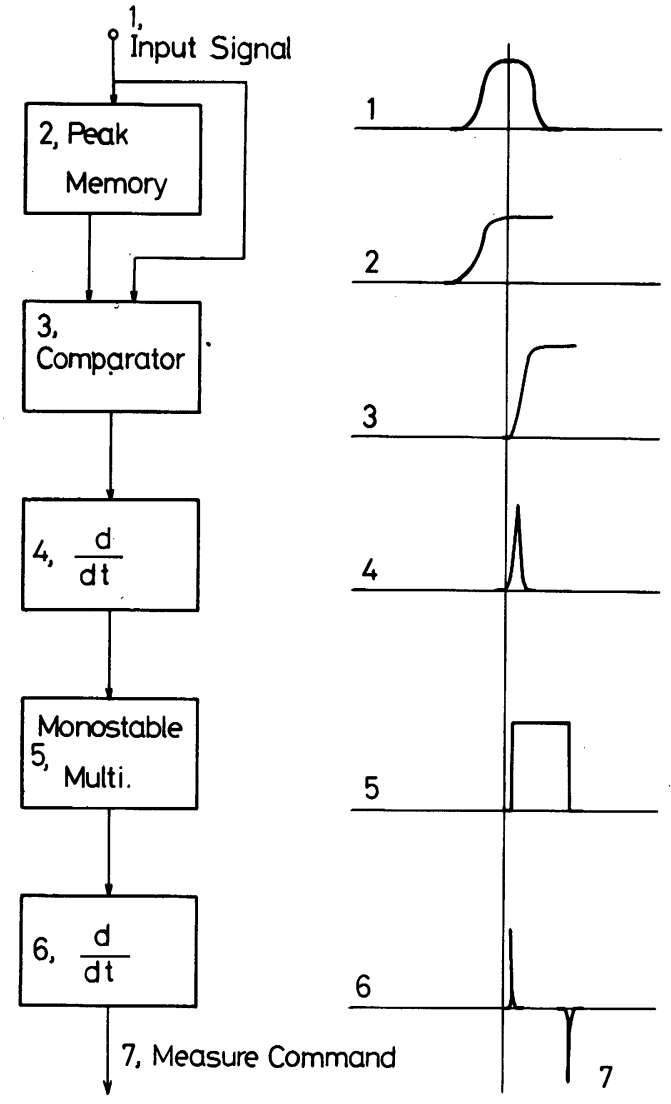

Fig. 4. Block diagram of the maximum detector and measure command circuit, and their wave forms.

持し，極大値に達した所で前記の測定指令により測定 が行なわれた後保持回路に保持された信号を自動的に 消去し，次の測定に備えなければならない。

単純な方法として測定指令後一定時間をおいて消去 を行なう方法も考えられるが，後で述べるレンジ切換 えの必要な場合は測定所用時間が長くなるし磁界偏向 型ではピークの幅も質量によって変わるため, 必要な 時間だけ信号を保持するよう回路を工夫しなければな らない。ここで注意しなければならないことは, 測定 の終了とピークそのものが零となる時点との前後関係 である。測定終了時に入力信号もすでに零となってい る場合は測定終了でもって消去信号を発生すればよい が, もし測定が終った時点でなお入力信号の裾が残っ ていると，消去を行なっても再びその時点の信号を保 持してしまうので，次にこれより小さい極大值を持つ 信号が来た場合には不都合がおこる。またこここで使 用した極大值検知の方法では，消去時点で残っていた 
入力信号はその後で入力がさらに減少するため極大值 と誤認されてしまう。

ところで，もし 2 本の隣あったスペクトル線の裾が 重なりあって十分に分離していない時はどうであろう か。この場合, 入力信号が零となっていなければ消去 しないとするとまた不都合が生じる。すなわち，もし 2つめのピークが先のものより低ければ, このピーク に対し測定指令が出ない。そこで，1つの消去信号は 入力信号が消失した時点ではなく，入力信号が極小值 となった時点で出すことにした。さらに，もう1つの 消去信号は D. V. M. による測定が終了した時点で出 すことにした。前者を第 1 消去信号，後者を第 2 消去 信号と呼ぶことにする。

この 2 つの消去信号の前後関係はピークの形と D. V. M. による測定所要時間によって変わるが，実際に

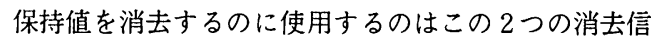
号の中で時間的に後のものでなければならない。

Fig. 5 は消去信号発生回路のブロック図である。第 1 消去信号は入力信号を微分して高利得の増幅器で十 分飽和するまで増幅した後再び微分し，これをトリガ 一として単安定マルチバイブレーターを働かせて消去 信号用パルスを作る。第 2 消去信号は D. V. M. から取 ク出した測定中信号（D. V. M. Busy）を微分しこれ をトリガーとして第 1 消去信号と同様に単安定マルチ バイブレーターを働かせて消去信号用パルスを作って いる。これらの消去信号はそれぞれ第 1 , 第 2 ゲート
回路を通るが，第 1 ゲート回路は測定中信号が存在す る間は第 1 消去信号を阻止する回路であり，第 2 ゲー 卜回路は入力信号の微分出力が負の期間 (入力信号の 絶対値が減少している期間) 第 2 消去信号の通過を阻 止する回路である。

各ゲートを通過した消去信号は O R 回路で合成され るが，第 1 ，第 2 消去信号を作る方法から考えて明ら かなごとく，消去信号が $2 つ$ つ゚ルスになることはな く，また2つのパルスが重なることはあるがパルスの 幅は変わらない。

第 1 ゲート回路は最初リニアーI C を用いた回路を 試みたが, 第 1 消去信号は入力信号の微分を用いてい るためノイズによる誤動作が時々出るので, 測定中信 号の存在する期間だけ阻止するゲートではなく, 測定 終了で閉回路となるが消去信号の通過が終った時点で 開路するものにした。このようにすることにより，先 の測定が終って消去が完了してから次の測定が始まっ て終了するまで消去信号は完全に阻止されるので, 誤 動作の危険がなくなった。Fig. 6 はこのゲート回路の 構成を示す図であり，七ットリセットフリップフロッ プ回路を用いたものである。第 1 消去信号が阻止され た場合でも消去動作が終了した時点でゲートは開路し なければならないから，第 1 消去信号と第 2 消去信号 を先にO R 回路で合成したものをこの第 1 ゲート回 路を通すようにした。このようにして得られた消去信 号はFig. 3 の增幅器 $\mathrm{A}_{3}$ の入力に導かれるが, 消去

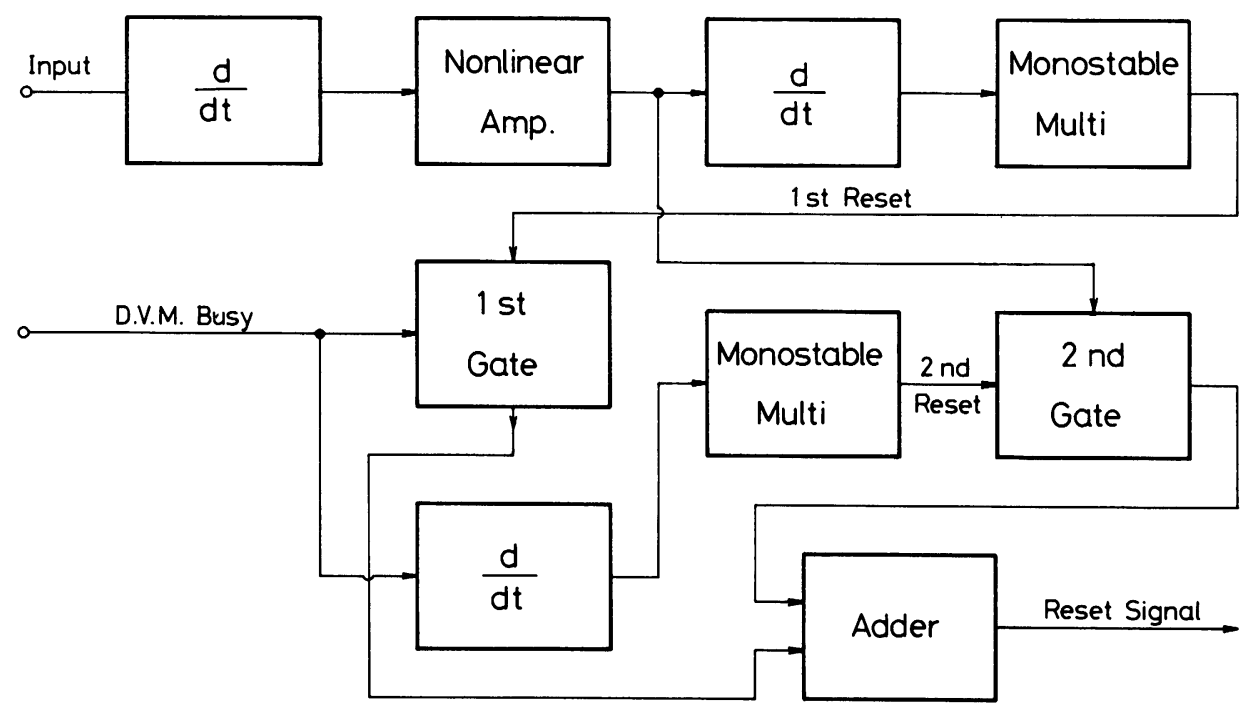

Fig. 5. Block diagram of the reset signal generator. 


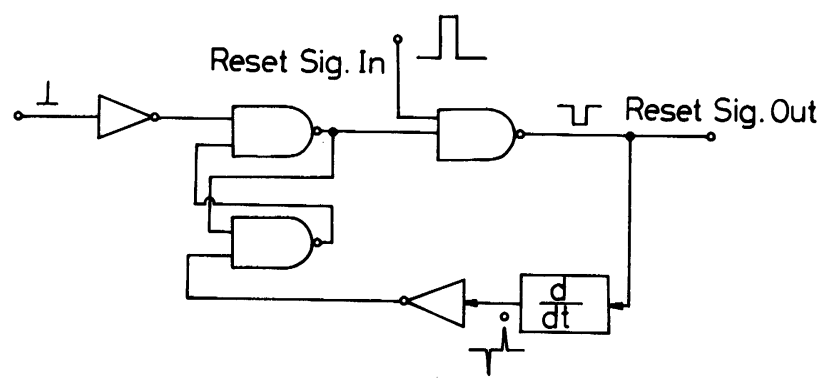

Fig. 6. Gate circuit for the reset signal.

信号は第 3 章でもふれたごとく正のバイアスがかかっ たものでなければならないから，可変抵抗 $\mathrm{R}_{11}$ でこの 值が設定できるようにした。なお，出力回路の $\mathrm{R}_{8}$ は 消去時の過渡的な振動を防ぐためのものである。

\section{6. 自動レンジ}

D. V.M. の自動レンジのものはいろいろ市販されて おり, リードリレーのような信頼性の高いリレーが普 及してこの部分での故障はあまり無いようであるので, 自動レンジの D. V. M. による質量スペクトルの測定 がうまくできると非常に好都合である。

ただ，われわれが使用した自動レンジの D. V. M.を 外部制御で使用する場合には，1つの測定指令を入れ るだけでレンジ変更の必要のある場合もない場合も同
じように作動するといつた便利なものでなく，1つの 測定指令によって測定操作が行なわれその結果レンジ が適正でない場合は数字はそのままで小数点のみが測 定の終りに右または左へ移動して停止する。そこで次 に同一の入力のままでもう一度測定指令を入れると， その新しく小数点が移動した状態が適正なレンジであ れば正しい数值が出るし，依然として不適正であれば 小数点はもう $1 つ$ 移動して停止する。このような機構 であるため, レンジが不適正の場合に 1 回目の測定が 終った時点で消去信号が出ることは都合が悪い。また， このような場合には再測定指令を出さねばならない。

一方, D. V. M. はその測定の結果小数点をシフトア ップないしはダウンする場合に，パルス信号を出す場 所があるからそこからシグナルを取出してこれにより

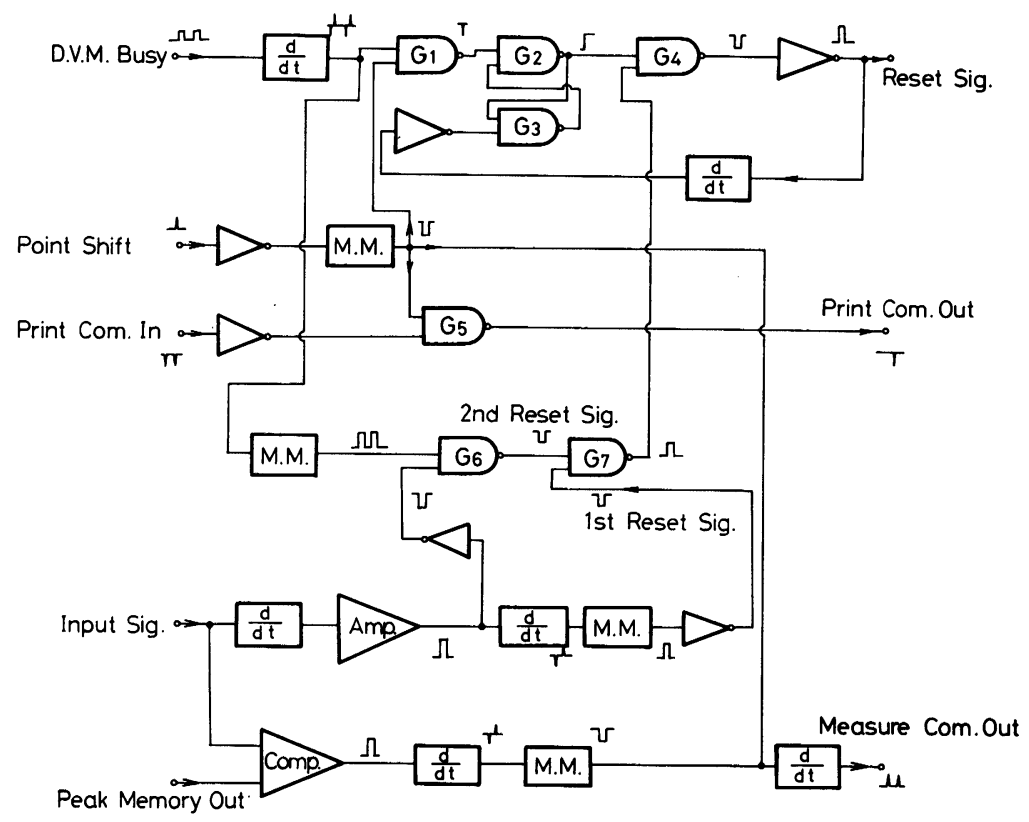

Fig. 7. Schematic diagram of the measure command, print command and reset signal generator. 
単安定マルチバイブレーターを働かせ, その出力を用 いて小数点シフト信号に続く測定終了の信号を阻止す るようにした。これが Fig. 7 の NANDゲート G であ る。 $\mathrm{G}_{2}, \mathrm{G}_{3}$ は Fig. 6 に示したセットリセットフリッ プフロップ回路であり，G4のゲートを制御している。 したがって, 消去信号のゲート $\left(G_{4}\right)$ は小数点シフト の信号のない場合の測定終了時にのみ閉路し，これを 通過した消去信号によって開路する。

小数点移動信号によってトリガーされる単安定マル チバイブレーターの出力はまた微分されて, その立上 りに同期して生じるパルス信号は測定指令信号として 使われ再測定の指令となる。

印字指令は D. V. M. から取り出されるが，小数点シ フトのある場合は最終的な測定の結果のみプリントす ればよいから，不必要な印字指令を阻止するためにG5 を設けた。なお， $G_{6}$ は第 2 消去信号を入力信号が減 少中は阻止するよう設けたゲートであり，G 1 消去信号と第 2 消去信号を $\mathrm{OR}$ 合成するための回路 である。

\section{7. 実験結果}

\section{1 動作筑囲}

質量分析計の出力信号は通常最大 $30 \mathrm{~V}$, 最小 $1 \mathrm{mV}$ ・位の範囲である。最大值はその増幅器の出しうる最大 電圧できまり, FET を使った直結型のものでは電源 電圧 $\pm 15 \mathrm{~V}$, 最大出力電圧 $10 \mathrm{~V}$ 位である。一方, 最 小信号はアンプのノイズレベルできまる。したがって, この装置もこの入力電圧範囲内で動作することが望ま しい。

われわれは回路をすべて $15 \mathrm{~V}$ の電源で動作する トランジスター式のオペレーショナルアンプを使用し たため, 各部分の最大出力電圧は $10 \mathrm{~V}$ 程度である。 例えば，極大值保持回路に保持しうる最大電圧は消去 信号のバイアス電圧できまるが, バイアス電圧を染く するとそれだけ消去信号の振幅を大にしなければなら ない。実験結果では $10 \mathrm{~V}$ 程度まで保持しうるよう調 整しうることがわかった。

最小電圧はこの場合やはりノイズレベルと関係する が, 測定指令が出るために必要な最小保持信号があっ て, これ以下の入力電圧では測定指令が出ない。測定 指令が出ないと消去信号も出ないため, このレベル以 下の信号が入ると保持されたままになる。この測定指 令を出しうる最小信号をより小さくするにはFig. 4の
比較増幅器の利得を上げればよいが, 動作が不安定に なるので限度がある。特に, 消去による過渡現象とし て保持回路が再充電されるという現象があり, $1 \mathrm{mV}$ 程度の信号が保持回路に残るため, それ以下の入力信 号に対しては正しい值を与えない。また, 雑音を信号 と誤認してプリントアウトすると, ペンレコーダーの チャートを見るのと違って，その数值を見て雑音か信 号かを判別することはむつかしい。したがって，ノイ ズレベルにあまり近い所まで動作することはかえって 不都合である。この装置では測定されうる最小信号を ほほ $3 \mathrm{mV}$ とした。

\section{2 記録の精度と確度}

われわれの使用した D. V. M. は 4 桁のもので通常有 効数字は 4 桁であるが, 最小単位が $0.1 \mathrm{mV}$ であるか ら $100 \mathrm{mV}$ あるいは $10 \mathrm{mV}$ 以下の入力の場合にはそ れぞれの有効数字は 3 桁および 2 桁となり, 小さい入 力の場合は当然精度は落ちる。一方, ペンレコーダー を使用した場合の読み取り精度はフルスケールで $1 / 1000$ が限度であり,それ以下の振れの時はそれよ り悪くなる。また，入力信号の小さい時は D. V. M.の 方が精度は落ちるが, 実際の入力は $0.1 \sim 0.3 \mathrm{mV}$ 位 の雑音があるためペンレコーダーの場合の精度も落ち る。以上のことから総合的にみて D. V. M. を使用する 方が精度は高い。なお， D. V. M. にはもっと有効数 字の多いものもあるが, 入力信号の雑音を減らさない 限り意味がない。次に確度であるが,これは D. V. M の確度とこの入力信号保持装置の確度に分けられる。 前者に関してはそれぞれのメーカーにおいてある一定 の確度が保証されており，それは一応十分に高いもの として, 保持回路の誤差がどれ位あるかを実測してみ た。

まず，電池を信号源として消去回路を働かさずに階 段状に入力電圧を変え, 同一の D. V. M. で入力電圧と 保持回路の出力電圧を読んだ結果をプロットしたのが Fig. 8 で, 縦軸には入力電圧と保持出力の差をとって ある。このグラフから入力と出力の間にほぼ $0.2 \% の$ 系統的誤差を含んでいることがわかる。また， -0.2 $\mathrm{mV}$ 程度の一定値の誤差も含まれているようである。 このような誤差は, 保持回路のオフセット調整とゲイ ンを正確に 1 に調整することにより小さくすることは 可能であるが，ゲインが 1 以下になると入力よりも 保持值が大となり, 入力の大きい時にその誤差が測定 指令信号を出しうる最小電圧を越え, 測定指令が出る 


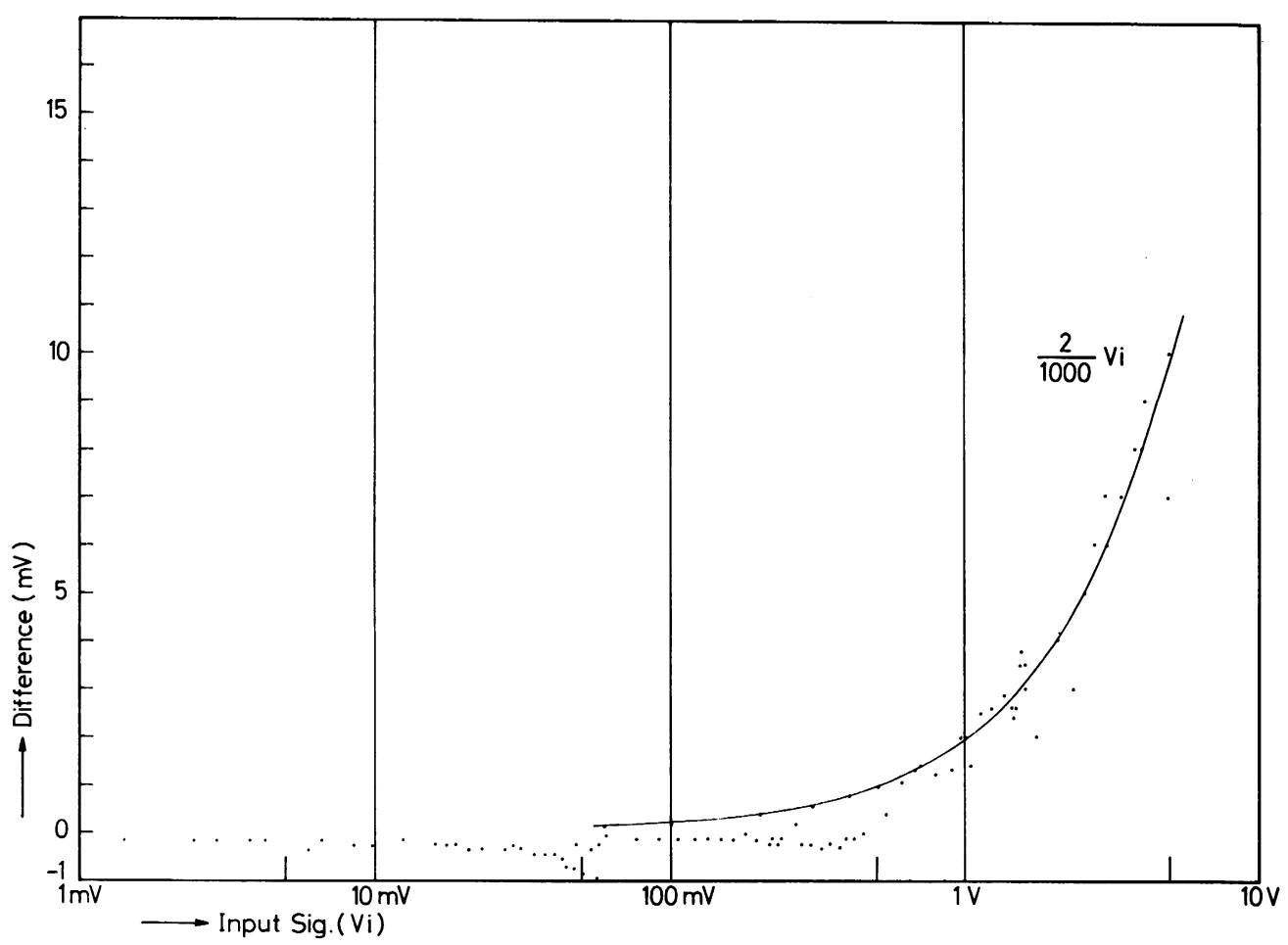

Fig. 8. Difference between input voltage and peak memory output voltage measured by the identical D. V. M.

危険がある。

同一の入力信号を繰返し入れた時の誤差は, 入力信 号が $100 \mathrm{mV}$ 程度の時末位の数字 $(0.1 \mathrm{mV})$ で士 1 程 度であった。同一の信号をD. V.M. とペンレコーダー で記録し，数值化した值とを比較してみると， $0.2 〜$ $0.3 \%$ 程 D. V. M. の指示が大であったが，これは $2 つ$ の測定器の絶対値のずれによるものである。測定值の ばらつきは $20 \mathrm{mV}$ 以上では $0.5 \%$ 程度の範囲内にあっ た。これは主としてチャートの読み取りの誤差による ものと思われる。なお, $20 \mathrm{mV}$ 以下では D. V. M. の 有効数字の減少によると思われる誤差が増大する。

電池を電源として可変抵抗を用いて任意のピーク高 さの信号を入れ，入力電圧をペンレコーダーで記録し， 保持回路の出力を D. V. M. で測定した結果を比較し て誤差をパーセントでプロットしたのがFig. 9 である。 記入した実線は D. V. M. の指示の末位の数字が \pm 1 だけちがった場合の計算上の誤差を示したもので, 測 定点がほぼこの線の間に入っていることから小さな入 力での誤差は主としてこの D. V. M. の精度に起因する 誤差と思われる。平均值が+ $0.5 \%$ あたりにあるのは
極大值保持回路と測定器の系統的誤差の和であり，入 力の大きい所でもある程度の誤差があるのは主として チャートの読み取り誤差であろう。

Fig. 10 は実際の質量分析計に接続して trans-2Buteneを流して測定した結果で, 通常の方法によるレ コーダーの記録とこの方法によるディジタル測定の結 果を比較したものである。Fig. 9 と比較してみると俁 差が増加している。その理由の 1 つはレコーダーをフ ルスケール $100 \mathrm{mV}$ ないしはそれ以上で使用したため, 20〜30 mV 以下では読み取り誤差がかなり増大したこ とにもよるが，もう1つは入力信号に含まれるノイズ の影響によるものと思われる。すなわち，チャート上 で $1 \mathrm{mV}$ 程度のノイズがみられるから, チャートから 読んだピークの高さの誤差はかなり大きくなる可能性 がある。この図に記入した実線は D. V. M. の数字の末 位の数字の土 2 による誤差の範囲を示したものであ る。

以上の結果から，このディジタル記録方法は数 $\mathrm{mV}$ から $10 \mathrm{~V}$ 位の入力範囲で十分にペンレコーダー記録以 上の精度および確度で測定しうることがわかった。 


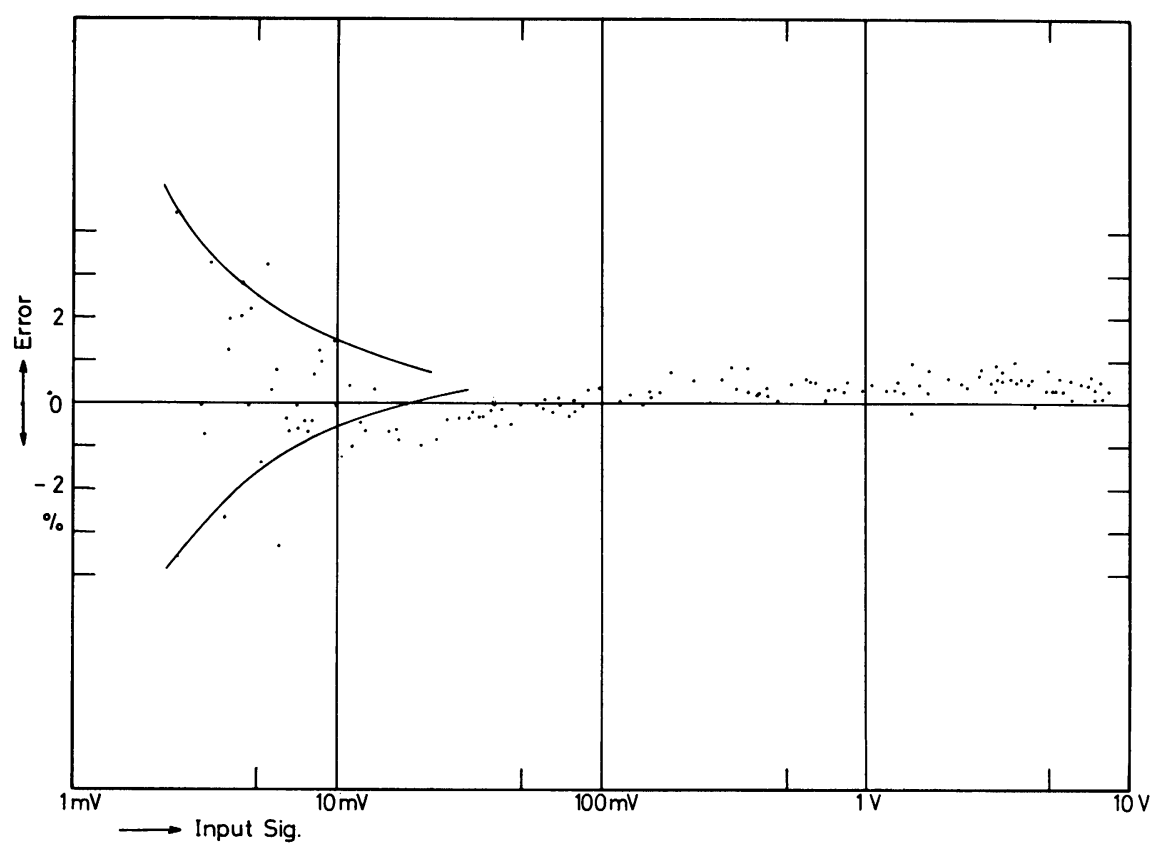

Fig. 9. Percent error between input voltage measured by a pen-recorder and output voltage measured by the D. V.M. In this case, the input signal was supplied by a battery and the potentiometer.

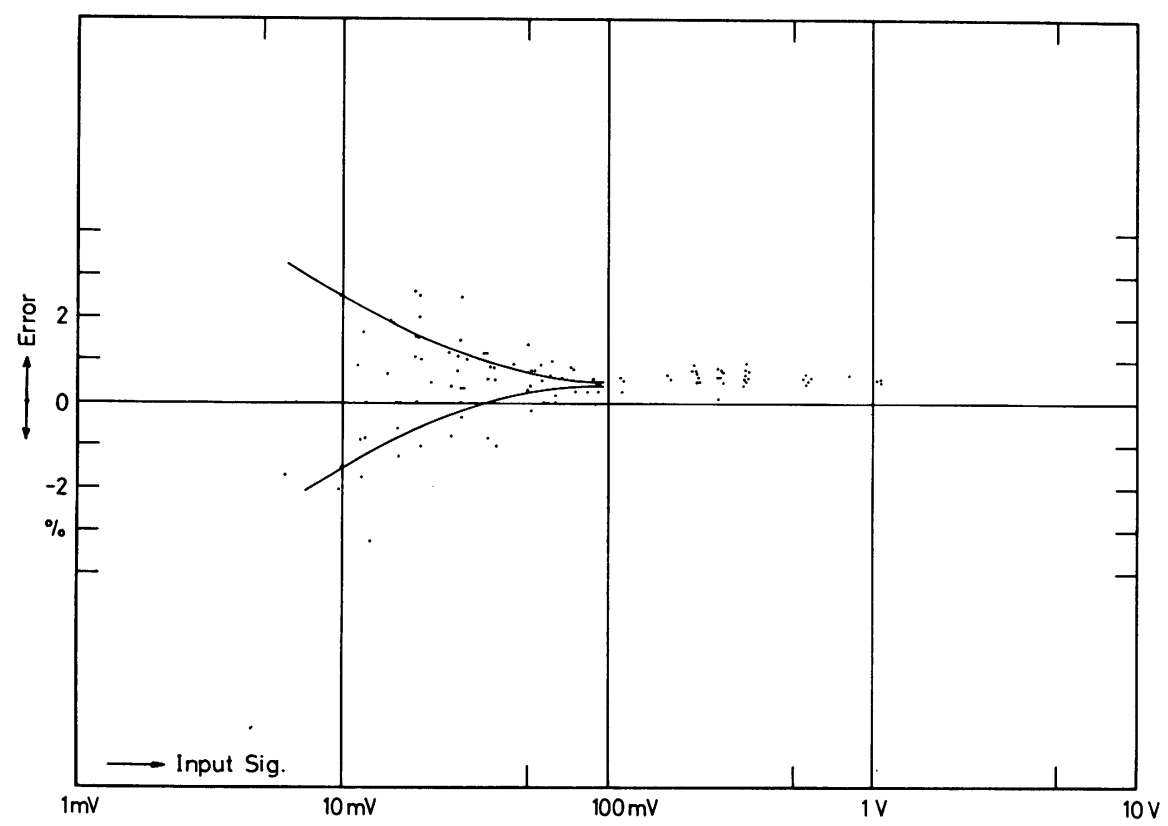

Fig. 10. Percent error between input voltage measured by a pen-recorder and output voltage measured by the D. V.M. In this case, the input signal was real output of the mass spectrometer. Sample gas was trans-2-Butene. 
なお，回路的には表題にかかげた程簡単ではなくな ったが，電子計算機を使うよりはやはり簡便ではない かと思われる。また，今後の問題としてどの位の速さ の掃引まで追随できるかといったことや，質量数も同 時に記録しなければ完全ではないといった問題が残さ れている。特に質量数の記録の問題は，質量スペクト ルが十分なフラットトップを持つよい装置であればあ る程ピークの中心を定めることが困難となり，質量数 の誤差が大きくなるであろうと考えられる。
終りに本研究の推進にあたり，御支援をいただいた 当社無線研究所所長城阪常務および当研究所杉原部長, ディジタルボルトメーターをお貸しいただき使用方法 に関し御教示いただいた松下通信工業(株)の松村課長, 大倉主任に厚く御礼申し上げます。

\section{文献}

1) 門田憲章·石田精一, 質量分析, No. 10, 25 (1958).

2 ）鈎三郎·堀田幸吉, 質量分析, 11，155 (1964).

3 ) Applications Manual for Operational Amplifiers Philbrick/Nexus Research (1968). 